\title{
Studi Analisis Perubahan Debit dan Tekanan Air Pada Pemodelan Pembangkit Listrik Tenaga Mikro Hidro
}

\author{
Made Angga Kharisma Krishnastana ${ }^{1}$, Lie Jasa ${ }^{2}$, Antonius Ibi Weking ${ }^{3}$
}

\begin{abstract}
Micro-Hidro power plant (PLTMH) is one of the alternative sources of power plant that use renewable energy in the form of water. This study analyzes the influence of change in water discharge and the water pressure against the torque, voltage, and the resulting electric current from generator. The result of the analysis on the changes of water discharge as well as changes in water pressure at the angle of the nozzle position $65^{\circ}$ and variation of nozzle $5^{0} ; 65^{0}$, the highest measurement result obtained on a half-circle vanes. On testing the changes of water discharge or water pressure, output voltage and the output current of the generator which is obtained on the half-circle vanes with the position of the nozzle $65^{\circ}$ i.e. of 1,994 Volt and 0,332 Ampere on changes of water discharge, as well as 1,326 Volt and 0,265 Ampere on changes of water pressure. Highest torque value is present on the vanes fins with nozzle variation $5^{0} ; 65^{0}$ namely $0.0159 \mathrm{Nm}$ on the changes of water discharge and 0.0122 $\mathrm{Nm}$ on the changes of water pressure.
\end{abstract}

Intisari-Pembangkit Listrik Tenaga Mikro Hidro (PLTMH) adalah salah satu alternatif sumber pembangkit yang menggunakan energi terbarukan berupa air. Penelitian ini menganalisis pengaruh perubahan debit dan tekanan air terhadap torsi, tegangan, dan arus listrik yang dihasilkan oleh generator. Hasil analisis pada perubahan debit air serta perubahan tekanan air pada sudut posisi nozzle $65^{\circ}$ dan variasi nozzle $5^{0}$ dan $65^{\circ}$, didapatkan nilai tertinggi pengukuran pada sudu setengah lingkaran. Pada pengujian perubahan tekanan maupun debit air, tegangan output dan arus output generator yang paling besar didapatkan pada sudu setengah lingkaran dengan posisi nozzle $65^{\circ}$ yaitu sebesar 1,994 Volt dan 0,332 Ampere pada perubahan debit air, serta 1,326 Volt dan 0,265 Ampere pada perubahan tekanan air. Nilai torsi tertinggi terdapat pada sudu setengah lingkarn dengan posisi nozzle $65^{\circ}$ yaitu sebesar $0.0159 \mathrm{Nm}$ pada perubahan debit air dan $0.0122 \mathrm{Nm}$ pada perubahan tekanan air.

Kata Kunci : PLTMH, Debit Air, Tekanan Air, Torsi

${ }^{1}$ Mahasiswa, Program Studi Teknik Elektro Fakultas Teknik Universitas Udayana, Br. Sema Bitera, Gianyar 80515 (Hp:083114736966; email:angga.kharisma99@gmail.com)

\footnotetext{
${ }^{2,3}$ Staf Pengajar Program Studi Teknik Elektro Fakultas Teknik Universitas Udayana, Jalan Kampus Bukit Jimbaran 80361 Indonesia (telp:0361-703315;fax: 0361-7013315)
} tony@unud.ac.id,liejasa@unud.ac.id

\section{PENDAHULUAN}

Energi air adalah salah satu sumber energi terbarukan yang berasal dari aliran air yang dimanfaatkan untuk menghasilkan energi listrik dengan cara menggunakan aliran air yang mengalir untuk memutar turbin, selanjutnya turbin dihubungkan dengan generator. Generator yang berputar akan mengubah energi putar hingga menghasilkan energi listrik. [1] Teknologi energi terbarukan memberikan harapan besar sebagai alternatif yang bebas polusi untuk menggantikan instalasi tenaga berbahan bakar nuklir dan fosil untuk memenuhi kebutuhan energi listrik. [2] PLTMH merupakan teknologi pembangkit listrik yang ramah lingkungan karena memanfaatkan aliran sungai atau aliran terjunan menjadi sumber energi listrik melalui turbin. [3] Pembangkit Listrik Tenaga Mikro Hidro (PLTMH) dipilih sebagai salah satu energi alternatif karena memiliki beberapa keunggulan dibandingkan pembangkit listrik lainnya. [4]

Penelitian ini dilakukan dengan melakukan perubahan debit dan tekanan air untuk mengetahui pengaruhnya terhadap kinerja dari sebuah pembangkit listrik tenaga mikro hidro, dan pada penelitian-penelitian sebelumnya masih belum ada yang melakukan perubahan debit dan tekanan air. Jenis-jenis sudu yang digunakan pada penelitian ini adalah sudu setengah lingkaran, sudu segitiga, dan sudu sirip. Berdasarkan kelebihan dan kekurangan masing-masing jenis sudu yang digunakan maka dilakukan penelitian menggunakan tiga jenis sudu turbin yang berbeda dengan melakukan perubahan debit air dan tekanan air pada posisi dan sudut nozzle yang telah ditentukan untuk mengetahui pengaruh debit dan tekanan air terhadap kecepatan putar kincir dan generator serta tegangan dan arus keluaran dari generator.

\section{STUDI PUSTAKA}

\section{A. Tekanan Air}

Tekanan merupakan gaya yang bekerja pada suatu bidang per satuan luas bidang tersebut. Tekanan air berfungsi untuk memutar kincir dengan kecepatan air. [5]

\section{B. Debit Air}

Debit air adalah besaran yang menyatakan banyaknya air yang mengalir selama satu waktu yang melewati suatu penampang luas. Besarnya nilai dari debit air dapat dihitung dengan persamaan : [5]

$$
\text { Debit }=\frac{\text { Volume bejana }}{\text { Waktu untuk memenuhi bejana }}
$$

Bejana yang digunakan pada penelitian ini adalah bejana ukur yang dapat dilihat seperti pada gambar 4 . 


\section{Torsi}

Torsi menunjukkan kemampuan sebuah gaya untuk membuat benda melakukan gerak rotasi. Besarnya torsi tergantung pada gaya yang dikeluarkan serta jarak antara sumbu putar dan letak gaya.

$$
T=\frac{P}{2 \pi \frac{n}{60}}
$$

Dimana :

$T=$ Torsi $(\mathrm{Nm})$

$P=$ Daya $(\mathrm{kW})$

$\mathrm{N}=$ Kecepatan putaran (rpm)

\section{Pembangkit Listrik Tenaga Mikro Hidro}

Pembangkit Listrik tenaga Mikro Hidro (PLTMH) adalah salah satu alternatif sumber pembangkit energi. Umumnya PLTMH adalah pembangkit listrik tenaga air jenis "run-ofriver" dimana head diperoleh tidak dengan cara membangun bendungan besar, tetapi dengan mengalihkan sebagian aliran air sungai melalui pipa atau saluran untuk turbin ke salah satu sisi sungai dan menjatuhkannya lagi ke sungai yang sama.

Pembangkit Listrik Tenaga Mikro Hidro (PLTMH) merupakan pembangkit listrik dengan daya keluaran dibawah $100 \mathrm{~kW}$. [6] Pada penelitian ini, daya yang dihasilkan oleh PLTMH yang diuji dibawah $100 \mathrm{~kW}$ dan masih relatif rendah.

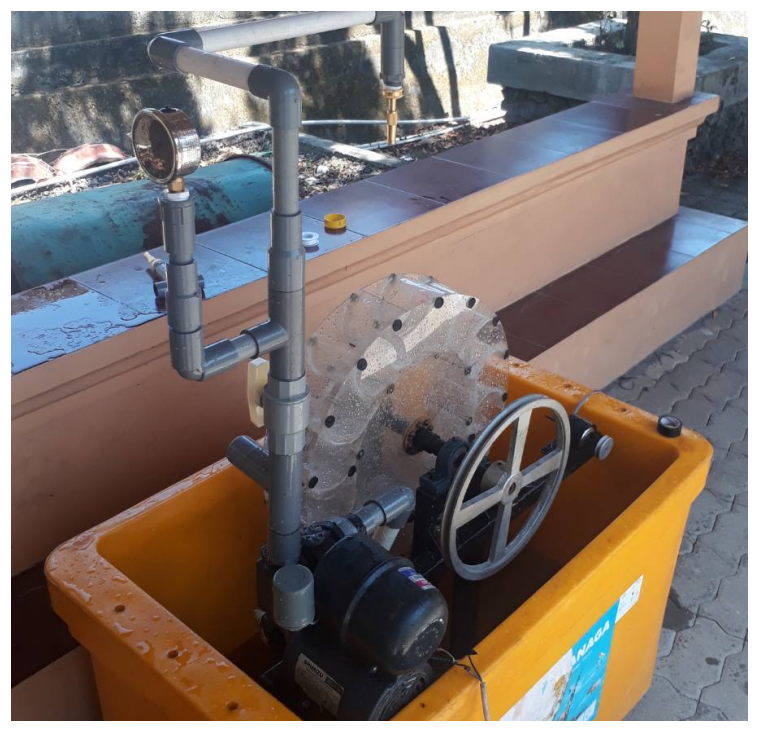

Gambar 1. Realisasi PLTMH yang diuji

G. Komponen Pembangkit Listrik Tenaga Mikrohidro

1) Pipa Pesat (penstock) ; digunakan sebagai jalur pengantar air dari bak tampungan menuju turbin. [7]

2) Governor : untuk mengatur masuknya air dari pipa pesat menuju turbin. [8]

3) Turbin Air : Turbin air adalah turbin dengan air sebagai fluida kerja. Turbin air berperan untuk mengubah energi air yaitu energi potensial, tekanan dan energi kinetik menjadi energi mekanik dalam bentuk putaran poros. [9]

4) Nozzle : Nozzle adalah alat atau perangkat yang dirancang untuk mengontrol arah atau karakteristik dari aliran fluida (terutama untuk meningkatkan kecepatan) saat keluar atau memasuki sebuah ruang tertutup atau pipa.

5) Generator: Generator digunakan untuk merubah energi putar menjadi energi listrik. [8] Berdasarkan arus yang dihasilkan, generator dapat dibedakan menjadi dua macam, yaitu generator AC dan generator DC. [10]

\section{H. Model Sudu Turbin}

Terdapat tiga model sudu turbin yang dipergunakan dalam penelitian ini, yaitu :

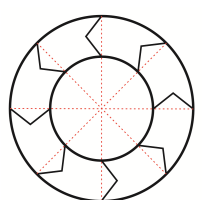

(a)

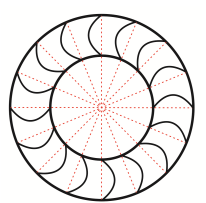

(b)

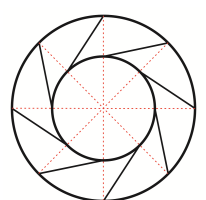

(c)
Gambar 2. (a) Sudu Segitiga. (b) Sudu Setengah Lingkaran, (c) Sudu Sirip

\section{Hasil Penelitian Yang Terkait}

Terdapat beberapa hasil penelitian yang telah dilakukan sebelumnya yang memiliki keterkaitan dengan penelitian ini, antara lain :

1) Penelitian yang dilakukan oleh Donny Christiawan pada tahun 2017 menganalisis pengaruh model sudu terhadap turbin pada PLTMH. Pada penelitian ini digunakan 3 jenis sudu yang berbeda dan diperoleh hasil pengukuran rpm tertinggi sebesar 151,6 dan torsi tertinggi sebesar 0,017 Nm pada sudut nozzle $30^{\circ}$ dengan menggunakan jenis sudu segitiga. Sedangkan untuk luasan volume debit air terbaik adalah sudu setengah lingkaran sebesar 3,19 liter.

2) Penelitian yang dilakukan oleh I Wayan Budiarsana Saputra pada tahun 2016 merancang pemodelan pembangkit listrik tenaga mikro hidro dengan menggunakan kincir overshot wheel. Pengukuran yang dilakukan pada pemodelan pembangkit listrik tenaga mikro hidro ini, meliputi : debit air, tekanan air, putaran kincir, putaran generator, tegangan, arus, serta daya output generator dan torsi serta efisiensi. Hasil pengukuran yang telah dilakukan terhadap parameter parameter pemodelan pembangkit listrik tenaga mikro hidro, diperoleh hasil pengukuran tertinggi pada sudut nozzle $30^{\circ}$. Daya output yang dihasilkan adalah 0,153 watt, torsi adalah $0,012 \mathrm{Nm}$ dan efisiensi sebesar 25,5\%.

3) Penelitian yang dilakukan oleh Achmad Bahri pada tahun 2016 menggunakan 3 jenis sudu yang berbeda. Berdasarkan hasil pengukuran dari prototype PLTMH, efisiensi turbin pada masing-masing sudu mencapai titik tertinggi pada sudut $30^{\circ}$. Pada sudut tersebut, efisiensi turbin sudu setengah lingkaran sebesar 0.26 , turbin sudu segitiga sebesar 0.46 dan efisiensi turbin sudu sirip sebesar 0.38 . Sehingga dari ketiga jenis sudu turbin tersebut, tingkat efisiensi turbin yang paling baik berdasarkan hasil pengukuran dari prototype yang telah dirancang adalah turbin sudu segitiga yang nilai efisiensinya sebesar 0.46 atau $46 \%$.

\section{METODOLOGI}

Secara sistematik, tahapan penelitian yang dilakukan dalam penelitian ini dapat dilihat pada gambar 3 . 


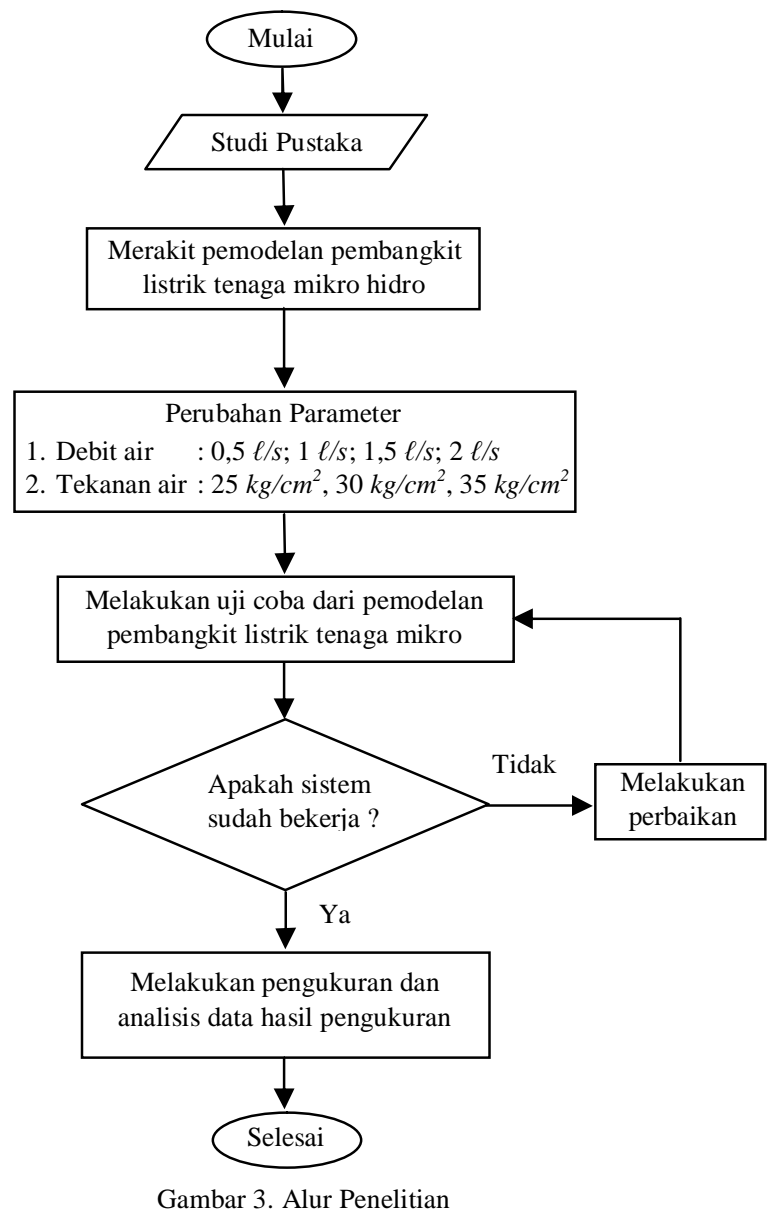

A. Studi Pustaka

Pada studi pustaka dilakukan dengan mencari referensi tentang energi air, potensi energi terbarukan, keunggulan pembangkit listrik tenaga mikro hidro, bagian-bagian PLTMH, parameter-parameter yang berpengaruh pada kinerja PLTMH, dan mencari jurnal-jurnal yang serupa dengan penelitian ini.

\section{B. Merakit Pemodelan PLTMH}

Pada proses perakitan pemodelan pembangkit listrik tenaga mikro hidro dalam penelitian ini dapat dijabarkan sebagai berikut :

1) Merakit kincir dan pompa dengan kerangkanya sehingga menjadi satu bagian.

2) Merakit instalasi perpipaan pada pemodelan pembangkit listrik tenaga mikro hidro yang berfungsi untuk mengalirkan air dari bak penampungan menuju turbin.

3) Memasang generator yang berfungsi untuk menghasilkan tegangan dan arus.

4) Merakit pulley kincir dan pulley generator agar dapat mengukur dan mencatat putaran pada kincir dan generator.

\section{Melakukan Perubahan Debit Air}

Pada tahapan perubahan debit air pada pemodelan pembangkit listrik tenaga mikro hidro mula-mula dilakukan dengan cara menghidupkan pompa sehingga air dari bak penampungan tersedot dan dialirkan melalui pipa, kemudian dilanjutkan dengan mengatur posisi governor kemudian mengukur debit air yang keluar pada nozzle dengan bejana ukur sehingga didapatkan debit air yang di inginkan.

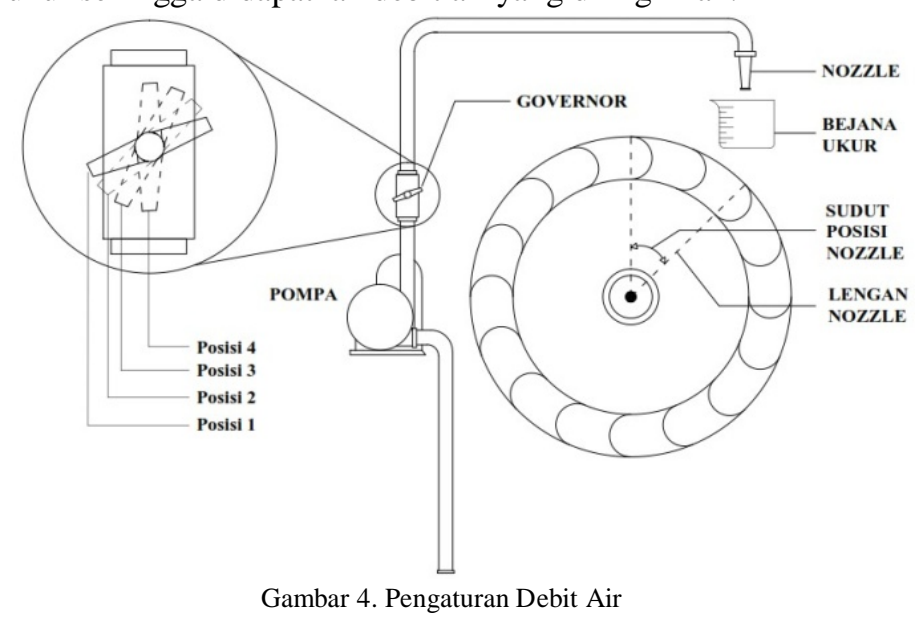

\section{Melakukan Perubahan Tekanan Air}

Pada pemodelan pembangkit listrik tenaga mikro hidro ini, mula-mula dilakukan dengan cara menghidupkan pompa sehingga air dari bak penampungan tersedot dan dialirkan melalui pipa, perubahan tekanan air dilakukan dengan mengatur governoor, yaitu berupa keran yang terpasang pada pipa pesat (penstock). Dengan menggunakan manometer yang terpasang pada pipa sebagai alat ukur untuk mengukur tekanan air.

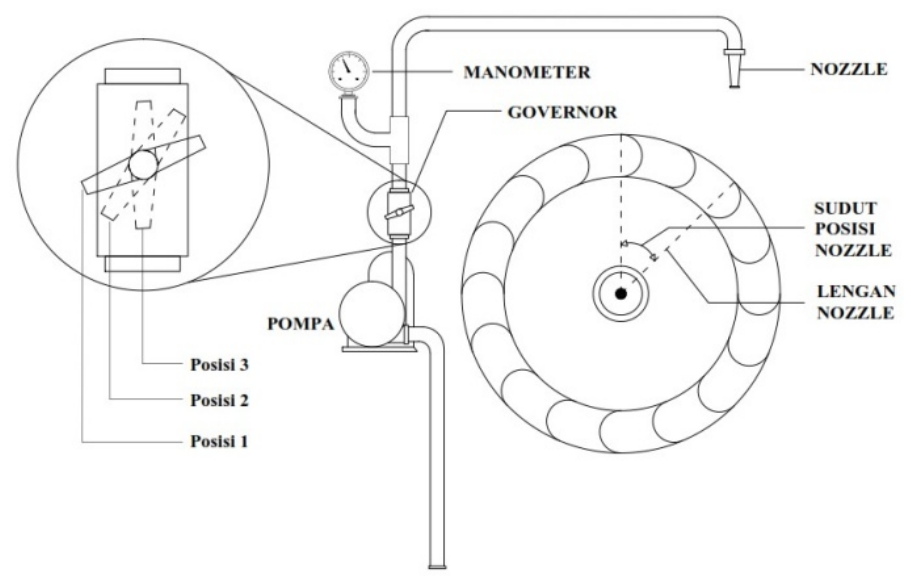

Gambar 5. Pengaturan Tekanan Air

\section{E. Melakukan Uji Coba}

Proses uji coba yang dilakukan antara lain :

1) Melakukan uji coba pada pompa dengan menghidupkan pompa.

2) Memeriksa bearing kincir dengan cara memutar kincir pada porosnya.

Made Angga Kharisma Krishnastana : Studi Analisis Perubahan Debit... 
3) Melakukan uji coba pada generator dengan cara mengukur tegangan generator saat poros generator diputar.

Jika proses uji coba tidak mengalami kendala maka dapat dilanjutkan ke tahap selanjutnya.

\section{F. Melakukan Pengukuran}

Setelah melakukan proses perakitan, maka dapat dilakukan uji coba dan pengambilan data yang dapat dijabarkan sebagai berikut :

1) Pengambilan data yang pertama yaitu melakukan perubahan pada debit air dan mengukur kecepatan rpm dari ketiga jenis turbin, kemudian dilakukan pula perubahan tekanan air sehingga didapatkan pengaruh perubahan takanan air terhadap putaran kincir.

2) Milakukan perhitungan torsi berdasarkan nilai kecepatan rpm dari ketiga jenis turbin.

3) Melakukan pengukuran tegangan dan arus keluaran dari generator pada masing - masing nilai debit dan tekanan air yang berbeda - beda.

\section{HASIL DAN PEMBAHASAN}

\section{A. Pengukuran dan Perhitungan Pemodelan PLTMH}

Pengukuran pemodelan (PLTMH) dilakukan bertujuan untuk mengetahui sejauh mana pemodelan yang sudah dirancang telah memenuhi harapan dan dapat sesuai perencanaan. Adapun pengukuran pada pemodelan pembangkit listrik tenaga mikro hidro yaitu : Pengukuran debit air, pengukuran tekanan air, pengukuran putaran kincir, pengukuran putaran generator, pengukuran tegangan generator, dan pengukuran arus generator.

Setelah mendapatkan data pengukuran, maka dapat dilakukan perhitungan pada daya generator dan torsi generator serta torsi kincir.

\section{B. Data Hasil Pengukuran Pemodelan PLTMH}

Data hasil pengukuran pemodelan PLTMH ini merupakan data rata-rata hasil pengukuran yang dilakukan lebih dari sekali.

1) Hasil pengukuran terhadap perubahan debit air

TABEL 1

HASIL PENGUKURAN PUTARAN KINCIR DAN GENERATOR

\begin{tabular}{|c|c|c|c|c|c|c|}
\hline \multirow{2}{*}{ No } & \multirow{2}{*}{$\begin{array}{l}\text { Jenis } \\
\text { Sudu }\end{array}$} & \multirow{2}{*}{$\begin{array}{c}\text { Debit } \\
\text { Air } \\
(\ell / s)\end{array}$} & \multicolumn{2}{|c|}{$\begin{array}{l}\text { Putaran Kincir } \\
\text { (rpm) }\end{array}$} & \multicolumn{2}{|c|}{$\begin{array}{c}\text { Putaran } \\
\text { Generator } \\
\text { (rpm) }\end{array}$} \\
\hline & & & $\begin{array}{c}\text { Posisi } \\
\text { Nozzle } \\
65^{\circ} \\
\end{array}$ & $\begin{array}{c}\text { Variasi } \\
\text { Nozzle } \\
5^{0} \& 65^{0}\end{array}$ & $\begin{array}{c}\text { Posisi } \\
\text { Nozzle } \\
65^{0} \\
\end{array}$ & $\begin{array}{c}\text { Variasi } \\
\text { Nozzle } \\
5^{0} \& 65^{0} \\
\end{array}$ \\
\hline 1 & \multirow{4}{*}{$\begin{array}{l}\text { Setengah } \\
\text { Lingkaran }\end{array}$} & 0,5 & 197.2 & 107.2 & 1469.6 & 770 \\
\hline 2 & & 1 & 254.6 & 133.2 & 1952.4 & 966.2 \\
\hline 3 & & 1,5 & 328.2 & 164 & 2373 & 1259.6 \\
\hline 4 & & 2 & 396.8 & 202.6 & 2810.8 & 1555.8 \\
\hline 5 & \multirow{3}{*}{ Segitiga } & 0,5 & 175 & 92.2 & 1267 & 656.4 \\
\hline 6 & & 1 & 230.6 & 109.6 & 1776 & 804.8 \\
\hline 7 & & 1,5 & 293.2 & 138.4 & 2173.4 & 1111.6 \\
\hline
\end{tabular}

\begin{tabular}{|c|c|c|c|c|c|c|}
\hline 8 & & 2 & 349.6 & 181.6 & 2596.8 & 1400 \\
\hline 9 & \multirow{4}{*}{10} & 0,5 & 157.8 & 76.6 & 1178 & 515.2 \\
\cline { 1 - 5 } & \multirow{3}{*}{\begin{tabular}{c} 
Sirip \\
\cline { 1 - 5 } 12
\end{tabular}} & 1 & 219 & 88.6 & 1593.6 & 612.2 \\
\cline { 1 - 6 } & & 1,5 & 263.6 & 120 & 2052 & 870.4 \\
\cline { 1 - 6 } & 2 & 317.2 & 155.4 & 2409.4 & 1125.8 \\
\hline
\end{tabular}

Dari penelitian yang dilakukan diketahui bahwa dengan melakukan peningkatan nilai debit air dari 0,5 liter/detik menjadi 1 liter/detik ( 2 kali lipat) pada posisi nozzle $65^{\circ}$ pada sudu setengah lingkaran, didapatkan bahwa peningkatan kecepatan putar kincir bertambah 57,4 rpm atau mencapai nilai $29 \%$, peningkatannya hanya sekitar $1 / 4$ kali saja. Sedangkan saat nilai debit air ditingkatkan dari 0,5 liter/detik menjadi 2 liter/detik (4 kali lipat), penigkatan kecepatan putar kincir meningkat sebesar 199,6 rpm atau 101\%, peningkatannya menjadi 2 kali semula.

Pada penggunaan dua buah nozzle juga dilakukan peningkatan nilai debit air dari 0,5 liter/detik menjadi 1 liter/detik (2 kali lipat) pada variasi nozzle $5^{0}$ dan $65^{\circ}$ pada sudu setengah lingkaran, didapatkan bahwa peningkatan kecepatan putar kincir bertambah $26 \mathrm{rpm}$ atau mencapai persentase $24 \%$, peningkatannya hanya sekitar 1/4 kali saja untuk peningkatan nilai debit air sebesar 2 kali lipat semula. Sedangkan saat nilai debit air ditingkatkan dari 0,5 liter/detik menjadi 2 liter/detik (4 kali lipat), penigkatan kecepatan putar kincir meningkat sebesar 95,4 rpm atau mencapai 89\%, peningkatannya hampir 2 kali semula dengan peningkatan debit air 4 kali dari semula.

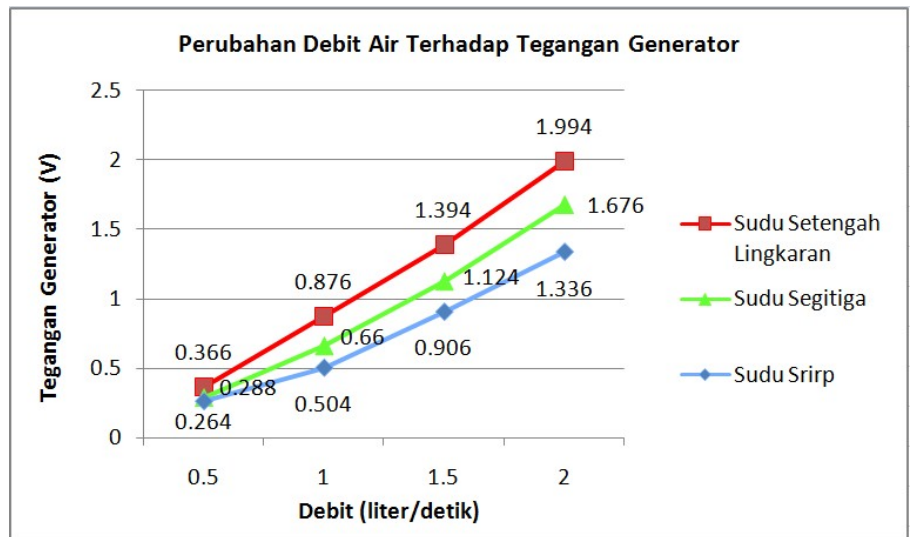

Gambar 6. Grafik perubahan debit air terhadap tegangan generator

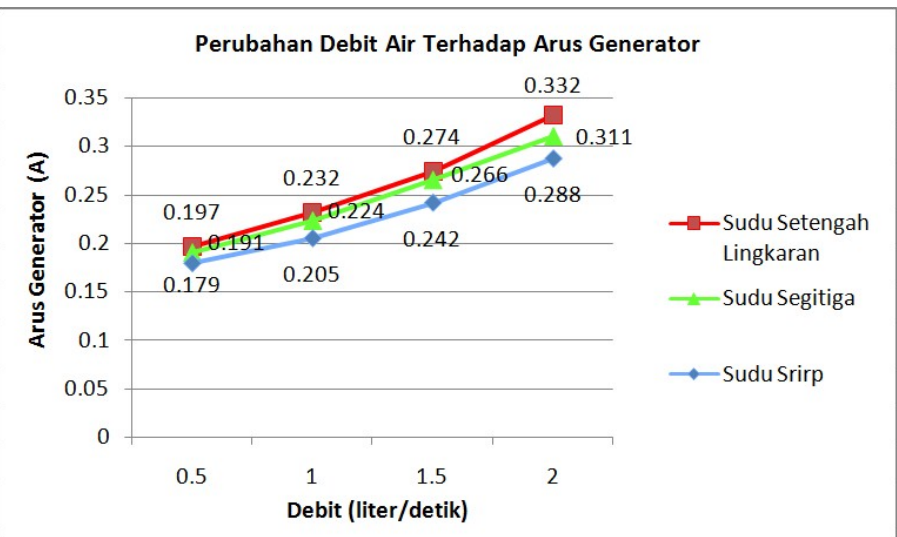

Gambar 7. Grafik perubahan debit air terhadap arus generator 
Tegangan dan arus output pada masing-masing jenis sudu mengalami peningkatan seiring dengan peningkatan debit air. Arus dan tegangan output generator tertinggi terdapat pada sudu setengah lingkaran sebesar 0,332 Ampere dan 1,994 Volt pada debit air 2 liter/detik. Sementara arus dan tegangan terendah pada debit air 2 liter/detik terdapat pada jenis sudu sirip sebesar 0,288 Ampere dan 1,336 Volt. Pada grafik terlihat bahwa semakin besar debit air maka semakin besar pula arus dan tegangan yang dihasilkan generator, begitu juga sebaliknya. Pada ketiga jenis sudu, nilai arus yang dihasilkan pada sudu setengah lingkaran lebih besar dibandingkan dengan sudu segitiga dan sirip.

TABEL 2

HASIL PERHITUNGAN DAYA GENERATOR

\begin{tabular}{|c|c|c|c|c|}
\hline \multirow{2}{*}{ No } & \multirow{2}{*}{ Jenis Sudu } & \multirow{2}{*}{$\begin{array}{c}\text { Debit Air } \\
(\ell / s)\end{array}$} & \multicolumn{2}{|c|}{$\begin{array}{l}\text { Daya } \\
\text { (VA) }\end{array}$} \\
\hline & & & $\begin{array}{c}\text { Posisi Nozzle } \\
65^{\circ} \\
\end{array}$ & \begin{tabular}{|c} 
Variasi Nozzle \\
$5^{0} ; 65^{0}$ \\
\end{tabular} \\
\hline 1 & \multirow{4}{*}{$\begin{array}{c}\text { Setengah } \\
\text { Lingkaran }\end{array}$} & 0,5 & 0.072 & 0.028 \\
\hline 2 & & 1 & 0.203 & 0.068 \\
\hline 3 & & 1,5 & 0.383 & 0.156 \\
\hline 4 & & 2 & 0.661 & 0.291 \\
\hline 5 & \multirow{4}{*}{ Segitiga } & 0,5 & 0.055 & 0.015 \\
\hline 6 & & 1 & 0.148 & 0.036 \\
\hline 7 & & 1,5 & 0.299 & 0.103 \\
\hline 8 & & 2 & 0.522 & 0.217 \\
\hline 9 & \multirow{4}{*}{ Sirip } & 0,5 & 0.047 & 0.009 \\
\hline 10 & & 1 & 0.103 & 0.023 \\
\hline 11 & & 1,5 & 0.219 & 0.070 \\
\hline 12 & & 2 & 0.384 & 0.150 \\
\hline
\end{tabular}

Dengan melakukan perubahan debit air dari 0,5 liter/detik menjadi 1 liter/detik pada posisi nozzle $65^{\circ}$ mengakibatkan kenaikan daya pada generator saat penggunaan kincir dengan jenis sudu setengah lingkaran mencapai 94\%, pada sudu segitiga $80 \%$, dan pada sudu sirip $73 \%$. Sedangkan pada saat perubahan debit air dari 0,5 liter/detik menjadi 2 liter/detik mengakibatkan kenaikan daya geretator saat menggunakan jenis sudu setengah lingkaran mencapai $306 \%$, pada sudu segitiga $316 \%$, dan pada sudu sirip mencapai $272 \%$.

2) Hasil perhitungan torsi

Pada pengujian pemodelan PLTMH telah didapatkan beberapa data hasil pengukuran yaitu : kecepatan putar kincir, kecepatan putar generator, tegangan, arus, serta daya output generator. Dari data hasil yang diperoleh tersebut maka dapat dihitung besar nilai torsi generator dan torsi kincir.

Daya nominal generator adalah 6 watt dan kecepatan putaran nominal generator adalah $1800 \mathrm{rpm}$, maka torsi pada generator dapat dihitung sebagai berikut :

$$
\begin{aligned}
T & =\frac{6}{2 * 3,14 * \frac{1800}{60}} \\
& =0,032 \mathrm{Nm}
\end{aligned}
$$

Daya output dan kecepatan putaran kincir berbeda setiap perubahan debit air, tekanan air, dan jenis sudu. Untuk keseluruhan perhitungan torsi pada setiap peribahan debit air, dan jenis sudu dapat dilihat pada tabel 3. Perhitungan torsi kincir pada debit air 2 liter/detik dengan jenis sudu setengah lingkaran pada posisi nozzle $65^{\circ}$ dapat dihitung sebagai berikut :

$$
\begin{aligned}
T & =\frac{0,661}{2 * 3,14 * \frac{396,8}{60}} \\
& =0,0159 \mathrm{Nm}
\end{aligned}
$$

\begin{tabular}{|c|c|c|c|c|}
\hline \multirow[b]{2}{*}{ No } & \multirow[b]{2}{*}{$\begin{array}{l}\text { Jenis } \\
\text { sudu }\end{array}$} & \multirow[b]{2}{*}{$\begin{array}{c}\text { Debit Air } \\
(\ell / s)\end{array}$} & \multicolumn{2}{|c|}{ Torsi (Nm) } \\
\hline & & & $\begin{array}{c}\text { Posisi } \\
\text { Nozzle } \\
6^{0} \\
\end{array}$ & $\begin{array}{l}\text { Variasi } \\
\text { Nozzle } \\
5^{0} ; 65^{0}\end{array}$ \\
\hline 1 & \multirow{4}{*}{$\begin{array}{l}\text { Setengah } \\
\text { Lingkaran }\end{array}$} & 0,5 & 0.0035 & 0.0025 \\
\hline 2 & & 1 & 0.0076 & 0.0045 \\
\hline 3 & & 1,5 & 0.0111 & 0.0091 \\
\hline 4 & & 2 & 0.0159 & 0.0137 \\
\hline 5 & \multirow{4}{*}{ Segitiga } & 0,5 & 0.003 & 0.0015 \\
\hline 6 & & 1 & 0.0061 & 0.0031 \\
\hline 7 & & 1,5 & 0.0097 & 0.0071 \\
\hline 8 & & 2 & 0.0142 & 0.0114 \\
\hline 9 & \multirow{4}{*}{ Sirip } & 0,5 & 0.0028 & 0.0012 \\
\hline 10 & & 1 & 0.0045 & 0.0025 \\
\hline 11 & & 1,5 & 0.0079 & 0.0056 \\
\hline 12 & & 2 & 0.0116 & 0.0092 \\
\hline
\end{tabular}

TABEL 3

HASIL PERHITUNGAN TORSI TERHADAP DEBIT AIR

Perubahan debit air dari 0,5 liter/detik menjadi 1 liter/detik pada posisi nozzle $65^{\circ}$ mengakibatkan kenaikan torsi saat penggunaan kincir dengan jenis sudu setengah lingkaran mencapai $72 \%$, pada sudu segitiga $68 \%$, dan pada sudu sirip $53 \%$. Sedangkan pada saat perubahan debit air dari 0,5 liter/detik menjadi 2 liter/detik mengakibatkan kenaikan torsi saat menggunakan jenis sudu setengah lingkaran mencapai $151 \%$, pada sudu segitiga $158 \%$, dan pada sudu sirip mencapai $138 \%$.

3) Hubungan Antara Debit Air dan Tekanan Air

Berdasarkan dari hasil data yang diperoleh, dapat pula diketahui hubungan antara debit air dan tekanan air pada pembangkirt listrik tenaga mikro hidro. Hubungan antara debit air dan tekanan air adalah berbanding lurus. Semakin meningkat besar tekanan air, maka akan terjadi peningkatan juga pada debit air, begitu pula sebaliknya. Hubungan antara debit air dan tekanan air dapat dilihat pada grafik berikut :

Made Angga Kharisma Krishnastana : Studi Analisis Perubahan Debit... 


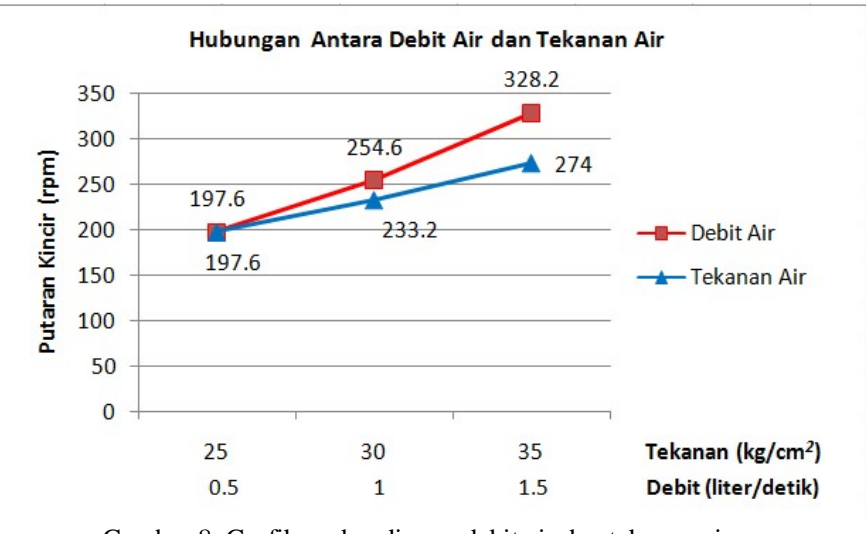

Gambar 8. Grafik perbandingan debit air dan tekanan air

Pada grafik perbandingan debit air dan tekanan air pada gambar diatas diambil dari perbandingan putaran kincir menggunakan jenis sudu setengah lingkaran pada perubahan debit air dan tekanan air. Dapat dilihat bahwa hasil dari putaran kincir besarnya sama pada saat debit air 0,5 liter/detik dan tekanan air $25 \mathrm{~kg} / \mathrm{cm}^{2}$. Sedangkan kecepatan putaran kincir meningkat lebih banyak pada peningkatan debit air daripada tekanan air, akan tetapi pada kecepatan putaran kincir saat debit air 1 liter/detik kurang lebih sama dengan kecepatan putar saat tekanan air $32 \mathrm{~kg} / \mathrm{cm}^{2}$. Berdasarkan grafik diatas, untuk menghasilkan putaran kincir yang baik untuk memutar generator agar menghasilkan tegangan yang besar adalah dengan melukan perubahan debit air daripada melakukan perubahan tekanan air. Dengan kata lain, perubahan debit air lebih efektif daripada perubahan tekanan air.

\section{KESIMPULAN}

Kesimpulan dari penelitian ini adalah :

1. Dengan sudut posisi nozzle $65^{\circ}$ dan variasi nozzle $5^{0} \& 65^{0}$ didapatkan nilai tertinggi pengukuran pada sudu setengah lingkaran pada perubahan debit air, hal ini dikarenakan sudu setengah lingkaran lebih baik dalam menampung volume air sehingga berat dari air yang tertampung pada sudu membantu kincir untuk menghasilkan putaran yang lebih tinggi pada jenis sudu setengah lingkaran daripada sudu yang lain.

2. Pada pengujian perubahan tekanan maupun debit air, tegangan output dan arus output generator yang paling besar didapatkan pada sudu setengah lingkaran dengan posisi nozzle $65^{\circ}$ yaitu sebesar 1,994 Volt dan 0,332 Ampere pada perubahan debit air, serta 1,326 Volt dan 0,265 Ampere pada perubahan tekanan air.

3. Pada pengujian pemodelan PLTMH dengan melakukan perubahan debit air dan tekanan air didapatkan nilai torsi yang lebih besar menggunakan posisi nozzle $65^{\circ}$ daripada variasi nozzle $5^{0} \& 65^{\circ}$ untuk nilai debit dan tekanan air yang sama. Nilai torsi tertinggi terdapat pada sudu setengah lingkaran dengan posisi nozzle $65^{\circ}$ yaitu sebesar $0.0159 \mathrm{Nm}$ pada perubahan debit air dan $0.0122 \mathrm{Nm}$ pada perubahan tekanan air.

\section{REFERENSI}

[1] L. Jasa. "Investigasi sudut Nozzle dan Sudut Kelengkungan Sudu Turbin Air Untuk Peningkatan
Efisiensi Mikro Hidro" (Disertasi). Surabaya : Institut Teknologi Sepuluh Nopember. 2015.

[2] Muliadi, E. W. Rahayu. Rancang Bangun Turbin Ulir Very Low Head Sebagai Pembangkit Listrik Tenaga Mikro Hidro. Media Bina Ilmiah Vol.10 No.4. ISSN:1978-3787.

[3] T. Rakhmawati, R. Hadiani, Solicin. Optimasi Diameter Pipa Pesat Pada Model Pembangkit Listrik Tenaga Mikro hidro (PLTMH). Surakarta : Universitas Sebelas Maret. 2016.

[4] Y. S. S. Putro, P. T. Juwono, P. H. Wicaksono. Studi Perencanaan Pembangkit Listrik Tenaga Mikro Hidro (PLTMH) di Sungai Atei Desa tumbang Atei Kecamatan Sanamang Mantikai Kabupaten Katingan Provinsi Kalimantan Tengah. Malang : Universitas Brawijaya. 2015.

[5] I W. B. Saputra. "Rancang Bangun Pemodelan Pembangkit Listrik Tenaga Mikro Hidro (PLTMH) Menggunakan Kincir Overshot Wheel." (Skripsi). Denpasar: Universitas Udayana. 2017.

[6] V. Dwiyanto, Dyah Indriana K., S. Tugiono. Analisis Pembangkit Listrik Tenaga Mikro Hidro (PLTMH). JRSSD, Vol. 4, No. 3 Hal:407 - 422 (ISSN:2303-0011).

[7] H. A. Nugroho. Perancangan dan Pembangunan Pembangkit Listrik tenaga Mikro Hidro. Yogyakarta : Universitas Ahmad Dahlan. 2017.

[8] A. I. Weking., L. Jasa., Y.P. Sudarmojo. Modul Simulasi Kontrol Hidro Power Untuk Praktikum Mahasiswa Teknik Elektro. Universitas Udayana, Badung. 2015.

[9] H. Wibowo, A. Daud, M. B. Al Amin. Kajian Teknis dan Ekonomi Perencanaan Pembangkit Listrik Tenaga Mikro Hidro (PLTMH) di Sungai Lematang Kota Pagar Alam. Sumatera Selatan : Universitas Sriwijaya. 2015.

[10]D. Christiawan. Studi Analisis Pengaruh Model Sudu pada Pembangkit Listrik Tenaga Mikro Hidro (PLTMH) (Skripsi). Denpasar: Universitas Udayana. 2017. 